\title{
Information Management of Health and Safety at the Tarkwa Mine of Goldfields Ghana Limited*
}

\author{
Y. Ofori and G. Pomfowaa
}

Ofori, Y. and Pomfowaa, G. (2016), "Information Management of Health and Safety at the Tarkwa Mine of Goldfields Ghana Limited” Ghana Mining Journal, Vol. 16, No. 1, pp. 106 - 112.

\begin{abstract}
The Tarkwa Mine (TM) of Goldfields Ghana Limited (GGL) undertakes open pit mining operations with gold recovery by heap leach technology. As a mine, it is susceptible to health and safety risks in its operations. In spite of health and safety policy and regulations put in place at the TM, there have been reported cases of some job-related injuries, accidents and diseases among the employees. Could it be that the employees are not aware of the health and safety policy and regulations? To answer this question, this paper sought to examine the level of employees' awareness of the health and safety policy and regulations, the suitability of the medium of information provision and the quality of information given to the employees on health and safety. The level of awareness of, and the suitability of the medium of information provision on, health and safety policy and regulations were assessed by analysing employees' responses obtained from questionnaire administration while the quality of information was assessed using the content of information from internal newsletters, brochures, notices and sign boards. It was found that majority of the employees are very much aware of the health and safety policy and regulations because of good mode and medium of information provision. Various ways of improving information provision at the TM of GGL to reduce health and safety risks have been provided.
\end{abstract}

Keywords: Information Provision, Awareness, Risk, Health and Safety Management

\section{Introduction}

The Tarkwa Mine (TM) of Goldfields Ghana Limited (GGL) is located in Tarkwa, the administrative capital of the Tarkwa-Nsuaem Municipal Assembly in south western Ghana. Tarkwa is about $300 \mathrm{~km}$ by road from Accra, the capital of Ghana (see Fig. 1). The TM of GGL, as a mine, is bound to experience health and safety issues in the course of its operations. For this reason, the company has put in place some health and safety measures to protect its employees from health and safety risks. The health and safety policy and regulations of the TM requires that a prospective employee is declared medically fit by a physician before appointment is given; every new employee goes through health and safety orientation and training programme; and every employee complies strictly with health and safety regulations. The medium of providing information on health and safety risks includes telephone, internet, signage, internal newsletters, brochures, bulletins and verbal instruction.

In spite of the health and safety policy and regulations put in place, there have been reported cases of some job-related injuries, accidents and diseases among employees of the TM of GGL. It is against this background that this study sought to examine the information provision mechanism put in place by the TM to inform the employees, and the level of awareness among the employees, of the health and safety policy and regulations put in place to protect the employees from health and safety risks.

The specific objectives of the study are to identify and examine the medium of information provision to employees at the TM of GGL, determine their effectiveness and make recommendations to improve them.

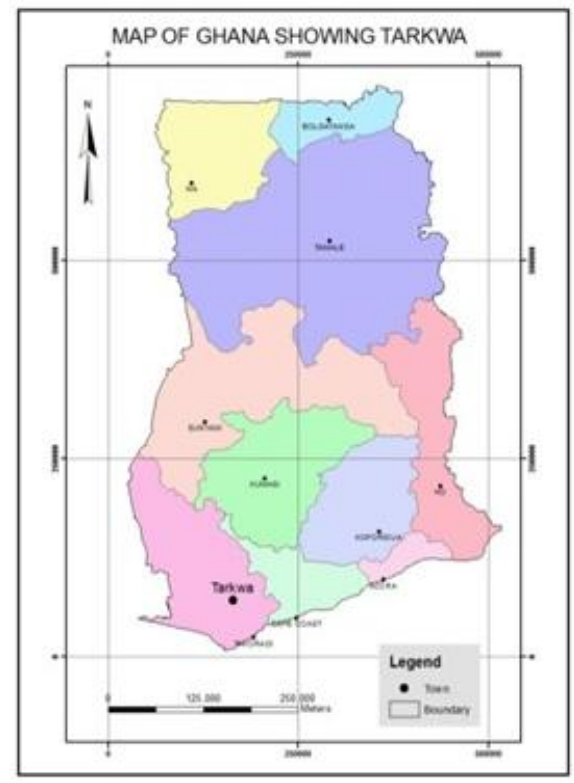

Fig. 1 Map of Ghana showing the location of Tarkwa 


\subsection{The Concepts of Information, Information Management and Risk}

Information has several dimensions. It means different things to different people. Some regard it as news while others regard it as facts and yet others regard it as data. Aina (2004) enumerated thirty (30) definitions of information, some of which include:

(i) Increasing the state of knowledge of a recipient;

(ii) Resolving uncertainty;

(iii) Adding value in decision making;

(iv) A physical surrogate of knowledge;

(v) All published and unpublished knowledge about a given subject; and

(vi) Body of knowledge.

The ambiguities in the meaning of information are underscored by Buckland (1991) when he characterised information to be a process, or knowledge. Information as a process means it is performing the function of informing, which involves transmitting message from a source to a destination. Information as knowledge is when it is performing the role of imparting knowledge to an individual, where it reduces uncertainty. Under the above circumstances the information is intangible. The other aspect of information is the intellectual content of physical object such as documents. This refers to information that has been recorded onto a medium that can be accessed and used by individuals. These include books, journals, microforms, , banners, sign posts, websites and the like.

According to Senn (1982) information is data that has been processed into a form that is meaningful to the recipient or the user, and is of real or perceived value in current or prospective decision process. In the context of communication the word 'information' is seen to be linked to the method by which we obtain data. Thus, one person gives information to another, who thereby becomes informed. Information is also defined as knowledge given or perceived of some fact or circumstance. Both definitions enumerated above sum up to one thing, that is, information aids decision making to reduce uncertainty.

Aina (2004) gave the relationship between data, information, knowledge and wisdom. According to him, data is raw and unprocessed, information is processed data from which meaning arises and it is communicated. When information is communicated, it is translated into knowledge of the recipient and may remain tacit or explicit. Tacit knowledge is the type of knowledge that remains in the head of individuals while explicit knowledge is the type of knowledge that has been recorded in a medium for all to access. Wisdom is knowledge applied to the benefit of society. From the above, the continuum data $\rightarrow$ information $\rightarrow$ knowledge $\rightarrow$ wisdom can be deduced. According to Senn (1982), information is characterised by such attributes as accuracy, form, frequency, breath, origin, time horizon, relevance, completeness, and timeliness. Absence of any of these attributes diminishes the worth of the information. This assertion is presented by Haag (2005) as shown in Fig. 2. Robek (1995), touching on the importance of information, indicated that people use information to protect themselves against occupational hazards.

There must also be a means of acquiring information by both management and staff. Information, being a great asset to any organisation, has to be made available to the right person, at the right time, at the right place, in the right form and with the right content.

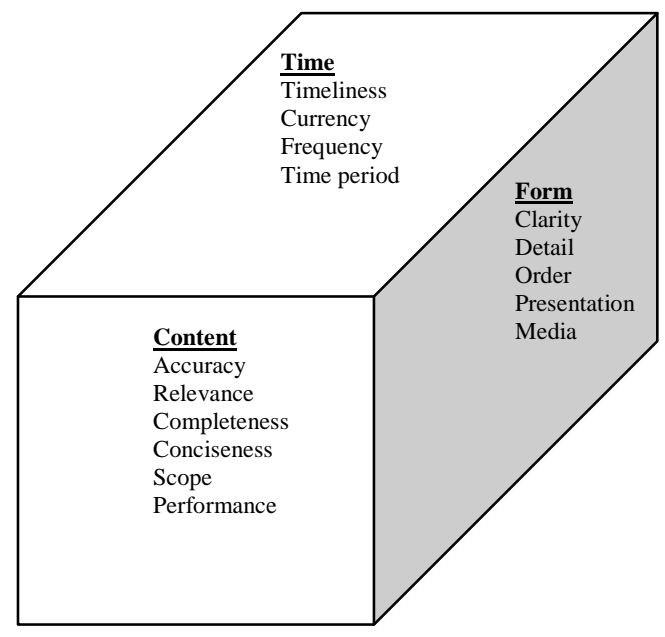

Fig. 2 Attributes of Information

Every functioning information system rests on proper information management practices. Information management is often defined as the administration, its use and dissemination, and the application of theories and techniques of information science to create, modify or improve information handling systems (Robek et al 2002). They argue that the degree of success of organizations and the people who work for them depends on how well they manage their information resources. Contributing to the debate on the challenges of information management, Nyoni (1998) indicated that in Africa information management has not escaped some of the pitfalls that most development initiatives have fallen into.

The term 'risk', in this context, is defined as the chance or probability that a person will be harmed or experience an adverse health effect if exposed to a hazard. Enumerating some of the risk exposures 
to a company, Reida (2008) mentioned that they include human resource loss exposures, part of which comprises job-related injuries, accidents and diseases experienced by employees. The issue of risk cannot be avoided. It can only be minimised and/or transferred. There is an inverse relationship between information provision and occurrence of risk. As information provision improves, the occurrence of risk reduces, and vice versa.

\section{Resources and Methods Used}

The sources of information used for the study were both primary and secondary. The primary sources consisted of data obtained from the administration of questionnaire, and the secondary sources were internally generated documents like newsletters, reports, brochures, notices, signage and bulletins. The questionnaire administration was used to collect primary data because data received from the responses of the employees would serve as a true reflection of what actually pertains in the mine as far as information provision is concerned. The secondary sources were used since they were emanating from management, and would determine how information is assimilated by the employees of the company.

The TM of GGL has a total of 3000 employees already stratified into the senior staff category numbering 1000 and junior staff category numbering 2000 For this study, five percent (5\%) of each category was set to be the sample size randomly selected, as it is regarded as an acceptable percentage to be used as a sample size (Saunders et al, 2012). The questionnaire was structured based on the objectives of the study. One senior staff and one junior staff of the TM of GGL were engaged to administer 150 sets of the questionnaires. The senior staff administered 49 sets to colleagues senior staff while the junior staff administered 101 to colleagues junior staff. All the sets of questionnaires were retrieved within two weeks. Open-ended and closed-ended questionnaires were administered to the respondents to solicit the required information from them.

Responses drawn from the questionnaire were coded, captured and analysed by the use of Statistical Package for Social Sciences (SPSS) software as it is very suitable for social research of this nature. Simple tables and graphs were generated from the data and analysed.

\section{Results and Discussion}

\subsection{Qualifications of Respondents}

The level of education of the employees determines the form in which information should be packaged for delivery. The study therefore sought to find out the educational qualifications and levels of the respondents; the result is shown in Table 1.

Table 1 Qualifications of Respondents

\begin{tabular}{|c|c|c|c|}
\hline \multirow{2}{*}{$\begin{array}{l}\text { Educational } \\
\text { Qualification }\end{array}$} & \multicolumn{2}{|c|}{ Category of staff } & \multirow[b]{2}{*}{ Total } \\
\hline & $\begin{array}{c}\text { Senior } \\
\text { Staff }\end{array}$ & $\begin{array}{c}\text { Junior } \\
\text { Staff }\end{array}$ & \\
\hline Tertiary & $\begin{array}{c}44 \\
(91.7 \%)\end{array}$ & - & $\begin{array}{c}44 \\
(13.6 \%)\end{array}$ \\
\hline $\begin{array}{l}\text { Post Secondary } \\
\text { Certificate }\end{array}$ & $\begin{array}{c}1 \\
(2.1 \%)\end{array}$ & $\begin{array}{c}1 \\
(1.0 \%)\end{array}$ & $\begin{array}{c}2 \\
(1.3 \%)\end{array}$ \\
\hline $\begin{array}{l}\text { SSCE/ /O’\&A } \\
\text { Levels }\end{array}$ & $\begin{array}{c}2 \\
(4.2 \%) \\
\end{array}$ & $\begin{array}{c}48 \\
(47.6 \%) \\
\end{array}$ & $\begin{array}{c}50 \\
(49 \%) \\
\end{array}$ \\
\hline Primary/JSS/MSL & $\begin{array}{c}1 \\
(2.1 \%) \\
\end{array}$ & $\begin{array}{c}50 \\
(49.5 \%) \\
\end{array}$ & $\begin{array}{c}51 \\
(34 \%)\end{array}$ \\
\hline No formal education & - & $\begin{array}{c}2 \\
(2.0 \%) \\
\end{array}$ & $\begin{array}{c}2 \\
(1.3 \%) \\
\end{array}$ \\
\hline Total & $\begin{array}{c}48 \\
(100 \%)\end{array}$ & $\begin{array}{c}101 \\
(100 \%)\end{array}$ & $\begin{array}{c}149 \\
(100 \%)\end{array}$ \\
\hline
\end{tabular}

It was observed that $91.7 \%$ of the senior staff had tertiary educational qualifications while in the case of the junior staff close to half of them $(49.5 \%)$ had basic and general education. Information delivery systems for the employees therefore should vary as their mental capacities to assimilate information differed. For this reason, health and safety risk information is provided to the employees in languages that can be understood by all. It was observed that the use of English, Akan and other foreign languages, such as French, together with the use of images and writings on sign boards in providing health and safety risk information, appeared to be understood and appreciated by the employees.

\subsection{Employees' Awareness of Health and Safety Policy and Regulations}

One of the objectives of the study was to examine the employees' awareness of health and safety policy and regulations of the TM of GGL. It was found out that the mine had a health and safety policy and regulations, and that all senior staff $(100 \%)$ and $99(98.6 \%)$ junior staff employees were aware of the existence of the policy. There were $2(2.19 \%)$ junior staff however, who were not aware of the existence of the health and safety policy and regulations, a potential recipe for the occurrence of job-related injuries, accidents and diseases (Strickland and Thompson, 1998). Management therefore has to do more in the area of creation of awareness among all employees.

Every company, and for that matter the TM of GGL must have a health and safety policy and regulations, the content of which must be accessible to all employees of the Mine. The study 
sought to find out from the respondents their source of knowledge of the health and safety policy and regulations. The responses gathered indicated that the employees were aware. And with regard to their source of knowledge $97 \%$ and $53 \%$ of senior and junior staff respectively indicated that their source of knowledge was the Risk Management Department of the mine as contained in Table 2 . This suggests that the Risk Management Department of the TM of GGL plays crucial role as far as provision of information on health and safety risks is concerned.

Table 2 Sources of Knowledge of Health and Safety Policy and Regulations

\begin{tabular}{||l|c|c|c||}
\hline \multirow{2}{*}{$\begin{array}{c}\text { Source of } \\
\text { Knowledge }\end{array}$} & \multicolumn{2}{|c|}{ Category of Staff } & \multirow{2}{*}{ Total } \\
\cline { 2 - 3 } & $\begin{array}{c}\text { Senior } \\
\text { Staff }\end{array}$ & $\begin{array}{c}\text { Junior } \\
\text { Staff }\end{array}$ & \\
\hline Colleagues & - & $\begin{array}{c}25 \\
(25.0 \%)\end{array}$ & $\begin{array}{c}25 \\
(17.6 \%)\end{array}$ \\
\hline $\begin{array}{l}\text { Information } \\
\text { Centre }\end{array}$ & 1 & $\begin{array}{c}22 \\
(2.4 \%)\end{array}$ & $\begin{array}{c}23 \\
(16.2 \%)\end{array}$ \\
\hline $\begin{array}{l}\text { Risk } \\
\text { Management } \\
\text { Dept }\end{array}$ & $\begin{array}{c}41 \\
(97.6 \%)\end{array}$ & $\begin{array}{c}53 \\
(53.0 \%)\end{array}$ & $\begin{array}{c}94 \\
(66.2 \%)\end{array}$ \\
\hline Total & $\begin{array}{c}42 \\
(100 \%)\end{array}$ & $\begin{array}{c}100 \\
(100 \%)\end{array}$ & $\begin{array}{c}142 \\
(100 \%)\end{array}$ \\
\hline
\end{tabular}

\subsection{Methods of Information Provision}

There are various platforms used to provide information to employees on their health and safety. The study found out from the respondents which platform was mostly used. Their responses are summarised in Table 3.

Table 3 Platforms for Providing Health and Safety Information

\begin{tabular}{|c|c|c|c|}
\hline \multirow{2}{*}{$\begin{array}{l}\text { Form of } \\
\text { Training }\end{array}$} & \multicolumn{2}{|c|}{ Category of Staff } & \multirow[b]{2}{*}{ Total } \\
\hline & $\begin{array}{c}\text { Senior } \\
\text { Staff }\end{array}$ & $\begin{array}{c}\text { Junior } \\
\text { Staff } \\
\end{array}$ & \\
\hline Workshops & $\begin{array}{c}8 \\
(16.7 \%)\end{array}$ & $\begin{array}{c}24 \\
(24.5 \%)\end{array}$ & $\begin{array}{c}32 \\
(21.9 \%)\end{array}$ \\
\hline $\begin{array}{l}\text { Departmental } \\
\text { forum }\end{array}$ & $\begin{array}{c}17 \\
(35.4 \%)\end{array}$ & $\begin{array}{c}29 \\
(29.6 \%)\end{array}$ & $\begin{array}{c}46 \\
(31.5 \%)\end{array}$ \\
\hline On-the- job & $\begin{array}{c}5 \\
(10.4 \%)\end{array}$ & $\begin{array}{c}33 \\
(33.7 \%)\end{array}$ & $\begin{array}{c}38 \\
(26.0 \%)\end{array}$ \\
\hline $\begin{array}{l}\text { Workshop, } \\
\text { Seminar and } \\
\text { on- the-job }\end{array}$ & $\begin{array}{c}1 \\
(2.1 \%)\end{array}$ & $\begin{array}{c}5 \\
(5.1 \%)\end{array}$ & $\begin{array}{c}6 \\
(4.1 \%)\end{array}$ \\
\hline $\begin{array}{l}\text { Seminars and } \\
\text { on-the-job }\end{array}$ & - & $\begin{array}{c}2 \\
(2.0 \%) \\
\end{array}$ & $\begin{array}{c}2 \\
(1.4 \%) \\
\end{array}$ \\
\hline $\begin{array}{l}\text { Workshop and } \\
\text { on-the-job }\end{array}$ & - & $\begin{array}{c}1 \\
(1.0 \%)\end{array}$ & $\begin{array}{c}1 \\
(0.7 \%)\end{array}$ \\
\hline $\begin{array}{l}\text { Workshops } \\
\text { and Seminars }\end{array}$ & $\begin{array}{c}17 \\
(35.4 \%) \\
\end{array}$ & $\begin{array}{c}4 \\
(4.1 \%) \\
\end{array}$ & $\begin{array}{c}21 \\
(14.4 \%) \\
\end{array}$ \\
\hline Total & $\begin{array}{c}48 \\
(100 \%)\end{array}$ & $\begin{array}{c}98 \\
(100 \%)\end{array}$ & $\begin{array}{c}146 \\
(100 \%)\end{array}$ \\
\hline
\end{tabular}

From the responses in Table 3, the senior staff indicated that workshops, seminars and departmental forums were mostly used to provide health and safety risks information to them. Among the junior staff on the other hand, they indicated that on- the- job training and departmental forum were used as the platform to provide health and safety risk information to them. This presupposes that there is a variety of ways through which health and safety risk information is provided to employees of the TM of GGL, though verbal instruction was the predominant medium.

These methods of information provision were found to be useful to the employees when they were asked to rate the quality of health and safety risk information given to them. Wlodowski (1985) has said that people learn trades in a masterapprentice relationship, and most of what they learn is on-the-job training. He therefore rates onthe-job training above the other means of health and safety information provision.

\subsection{Frequency of Health and Safety Training Programmes}

Information provision for employees to equip them with awareness of the hazard associated with their work environment should be an ongoing process and regularly organised so that employees would be constantly reminded to be health and safety conscious. The study sought to seek from the respondents the frequency at which health and safety training programmes was organised for them. It was observed, as in Table 4, that close to half the respondents $(48 \%)$ indicated that health and safety training programmes was organised for them on a quarterly basis.

Table 4 Frequency of Training Programmes

\begin{tabular}{|c|c|c|c|}
\hline \multirow{2}{*}{$\begin{array}{l}\text { Training } \\
\text { Interval }\end{array}$} & \multicolumn{2}{|c|}{ Category of Staff } & \multirow{2}{*}{ Total } \\
\hline & Senior Staff & Junior St & \\
\hline 1 Monthly & $12(25.0 \%)$ & $19(20.4 \%)$ & $31(22.0 \%)$ \\
\hline Quarterly & $31(64.0 \%)$ & $38(4$ & 69 \\
\hline 6 Monthly & - & $10(10.8 \%)$ & $10(7.1 \%)$ \\
\hline Irregularly & $4(8.3 \%)$ & $26(28.0 \%)$ & $30(21.3 \%)$ \\
\hline Annually & $1(2.1 \%)$ & - & $1(0.7 \%)$ \\
\hline Total & $48(100 \%)$ & $93(100 \%)$ & $141(100 \%)$ \\
\hline
\end{tabular}

The timeliness of health and safety risk information provided to employees is very crucial. It was observed that it was appropriate for them to be equipped with health and safety risk information before and during work. The reason is that it would help them to prevent injuries and other forms of accidents.

The study revealed that the employees (74\%) received health and safety risk information before 
they started their daily routine work, while $25 \%$ of them indicated that they received health and safety risk information before and during work. It could therefore be seen that providing needed health and safety information to employees while working was non prevalent. The result of this has sometimes been incidents of accidents and injuries, and sometimes deaths of employees as reported by Turner (2010), which becomes a cause for concern. Information therefore needs to be provided to an employee while working as well to keep him on the alert always.

\subsection{Medium and Language of Information Provision}

When information is provided to an individual or group, it must be well understood in order to serve its purpose. For this reason the language of instruction should be very convenient and understandable to the recipient. The study therefore sought to find out the language used to provide health and safety risk information to employees at the mine. Their responses are as summarised in Table 5.

Table 5 Languages of Information Communication

\begin{tabular}{|l|c|c|c||}
\hline \multirow{2}{*}{ Language } & \multicolumn{2}{|c|}{ Category of Staff } & \multirow{2}{*}{ Total } \\
\cline { 2 - 3 } & $\begin{array}{c}\text { Senior } \\
\text { Staff }\end{array}$ & $\begin{array}{c}\text { Junior } \\
\text { Staff }\end{array}$ & \\
\hline English & $\begin{array}{c}8 \\
(19.0 \%)\end{array}$ & $\begin{array}{c}48 \\
(48.5 \%)\end{array}$ & $56(39.7 \%)$ \\
\hline $\begin{array}{l}\text { Akan and } \\
\text { French }\end{array}$ & - & $\begin{array}{c}2 \\
(2.0 \%)\end{array}$ & $2(1.4 \%)$ \\
\hline $\begin{array}{l}\text { English } \\
\text { and } \\
\text { Akan }\end{array}$ & 34 & 49 & 83 \\
\hline Total & $\begin{array}{c}42 \\
(100 \%)\end{array}$ & $\begin{array}{c}99 \\
(100 \%)\end{array}$ & $\begin{array}{c}141 \\
(100 \%)\end{array}$ \\
\hline
\end{tabular}

From the responses obtained from the respondents, both junior and senior staff indicated that health and safety risk information was provided to them in both English language and local Akan languages. This is seen to be a good practice as a section of the employees who are not well-versed in one of the languages would benefit from the other. A visit to the mine also revealed that in some cases information is provided in French language as well for whom it may concern as confirmed in signage (see Fig. 3). The medium and language through which health and safety risk information was provided were found to be generally good, and the employees were satisfied with them. The medium of information communication includes telephone, internet, internal newsletters, brochures and signage.

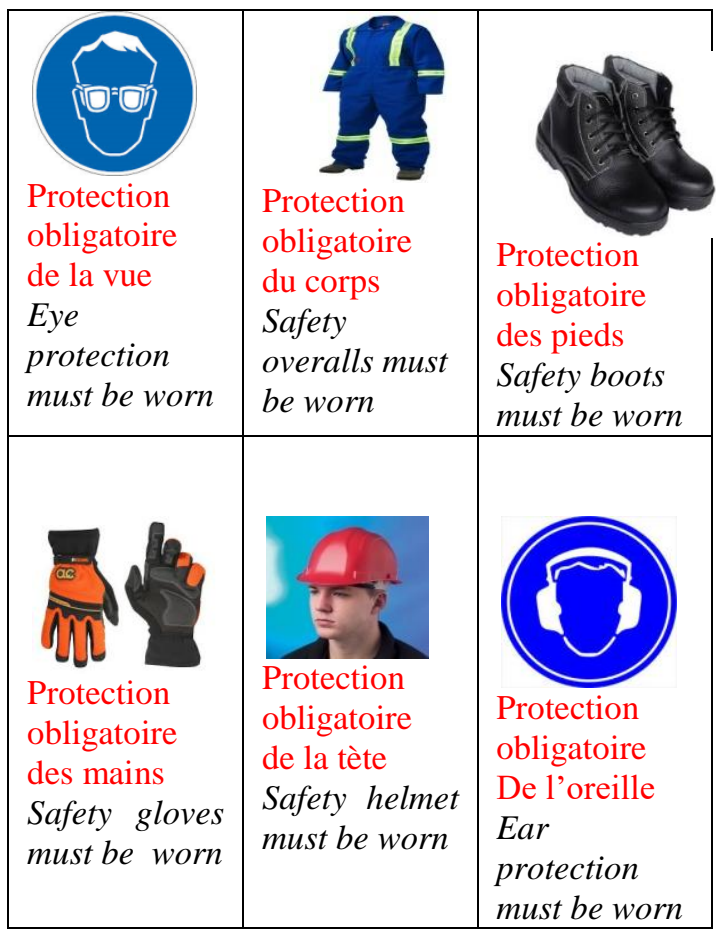

Fig. 3 Safety signage

The erection of sign boards to provide information to employees was also found to be a powerful tool as they are self explanatory, and mostly do not need very high educational level to understand them.

\subsection{Quality of Information}

Information, as already stated, must possess certain qualities if it is to serve its purpose effectively. Such qualities include relevance, correctness, accuracy, precision, completeness, timeliness, usability, accessibility, consistency and clarity. In this regard, the respondents were requested to rate those qualities as far as information provision on health and safety policy and regulations was concerned. They were required to rate the qualities on a scale of 1 to 5 under 'Very Low', 'Low', 'Moderate', 'High' and 'Very High. The results are shown in Fig. 4.

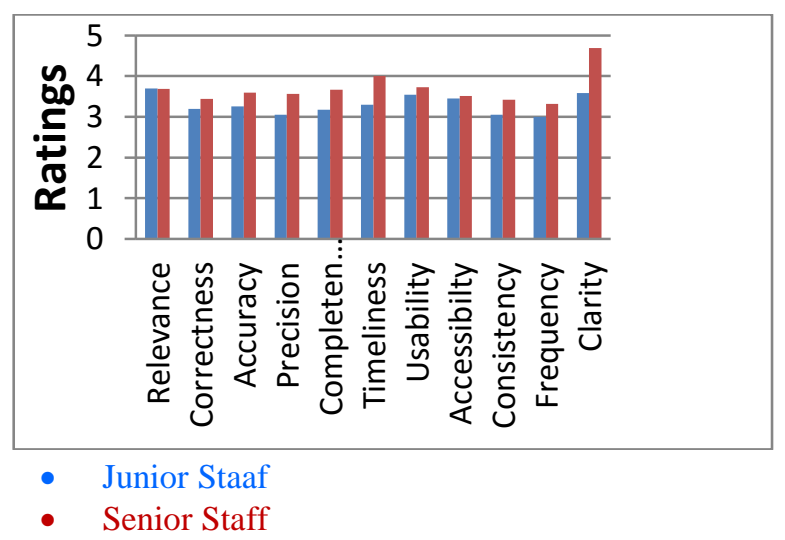

Fig. 4 Rated Quality of Information 
The responses gathered indicated that both senior and junior staff $(100 \%)$ rated the qualities between 3.0 and 4.69 , that is, between 'moderate' and 'very high'. This means that health and safety risk information provided in the mine met the required qualities. The employees contended that at least health and safety risk information provided helped prevent accidents and other forms of injuries.

\subsection{Types of Injuries}

Injuries and accidents that have been occurring at the TM of GGL have been of various dimensions. The following types of injuries are identified in a mine: lost time injuries refer to those injuries that restrict the injured person from duty for at least a day; medical treated injuries are those injuries in which medical attention is given for the injured person to return to post; minor injuries are injuries to tendons, ligaments, or muscles which does not result in serious impairment to the injured person (Anon, 2009c); medical injuries are any untoward harm associated with a therapeutic or diagnostic health care intervention and no preliminary screen (Wlodowski, 1985); total injuries are those caused by work injury or illness other than death that permanently or totally incapacitate a worker from following any gainful occupation, or that results in the loss, or the complete loss of use, of any combination of arms, legs, feet or eyes (Anon, 2009 b). One other injury worthy of mentioning is fatal injuries, which are injuries that cause death of individuals, or that is threatening enough to terminate the lives of individuals.

The study revealed, as shown in Table 6, that cuts are the most prevalent injuries $(66 \%$ of the respondents), followed by the combination of cuts and amputation (14.7\% of the employees). This means that lost time injuries and total injuries do occur in the mine, even though a total of 108 employees $(81.2 \%)$ indicated that they did occur irregularly.

From Table 7, 79.6\% and 33\% respondents of senior and junior staff respectively indicated that health and safety risk information provided them had been very significant or useful in reducing injuries and other forms of accidents.
Table 6 Prevalent Job related Injuries

\begin{tabular}{|c|c|c|c|}
\hline \multirow[b]{2}{*}{ Injury } & \multicolumn{2}{|c|}{ Category of Staff } & \multirow[b]{2}{*}{ Total } \\
\hline & $\begin{array}{c}\text { Senior } \\
\text { Staff }\end{array}$ & $\begin{array}{l}\text { Junior } \\
\text { Staff }\end{array}$ & \\
\hline Cuts & $\begin{array}{c}39 \\
(79.6 \%) \\
\end{array}$ & $\begin{array}{c}60 \\
(59.4 \%) \\
\end{array}$ & $\begin{array}{c}99 \\
(66.0 \%)\end{array}$ \\
\hline $\begin{array}{l}\text { Amputations } \\
\text { and Cuts }\end{array}$ & $\begin{array}{c}6 \\
(12.2 \%) \\
\end{array}$ & $\begin{array}{c}16 \\
(15.8 \%)\end{array}$ & $\begin{array}{c}22 \\
(14.7 \%) \\
\end{array}$ \\
\hline $\begin{array}{l}\text { Cutsand } \\
\text { Burns }\end{array}$ & $\begin{array}{c}1 \\
(2.0 \%) \\
\end{array}$ & $\begin{array}{c}15 \\
(14.9 \%) \\
\end{array}$ & $\begin{array}{c}16 \\
(10.7 \%) \\
\end{array}$ \\
\hline $\begin{array}{l}\text { Amputations, } \\
\text { Cuts and } \\
\text { Burns }\end{array}$ & $\begin{array}{c}3 \\
(6.1 \%)\end{array}$ & $\begin{array}{c}2 \\
(2.0 \%)\end{array}$ & $\begin{array}{c}5 \\
(3.3 \%)\end{array}$ \\
\hline Burns & - & $\begin{array}{c}4 \\
(4.0 \%)\end{array}$ & $\begin{array}{c}4 \\
(2.6 \%)\end{array}$ \\
\hline Amputation & - & $2(2.0 \%)$ & $2(1.3 \%)$ \\
\hline $\begin{array}{l}\text { Amputation } \\
\text { and Burns }\end{array}$ & - & $\begin{array}{c}1 \\
(1.0 \%) \\
\end{array}$ & $\begin{array}{c}1 \\
(0.7 \%) \\
\end{array}$ \\
\hline Total & $\begin{array}{c}49 \\
(100 \%)\end{array}$ & $\begin{array}{c}101 \\
(100 \%)\end{array}$ & $\begin{array}{c}150 \\
(100 \%)\end{array}$ \\
\hline
\end{tabular}

Table 7 Information Provision and Accident Reduction

\begin{tabular}{|c|c|c|c|}
\hline \multirow{2}{*}{$\begin{array}{c}\text { Degree of } \\
\text { Accident } \\
\text { Reduction }\end{array}$} & \multicolumn{2}{|c|}{ Category of Staff } & \multirow[b]{2}{*}{ Total } \\
\hline & $\begin{array}{c}\text { Senior } \\
\text { Staff }\end{array}$ & $\begin{array}{c}\text { Junior } \\
\text { Staff }\end{array}$ & \\
\hline Very Significant & $\begin{array}{c}39 \\
(79.6 \%)\end{array}$ & $\begin{array}{c}33 \\
(33.7 \%)\end{array}$ & $\begin{array}{c}72 \\
(49.0 \%)\end{array}$ \\
\hline Significant & $\begin{array}{c}10 \\
(20.4 \%)\end{array}$ & $\begin{array}{c}37 \\
(37.8 \%)\end{array}$ & $\begin{array}{c}47 \\
(32.0 \%)\end{array}$ \\
\hline Moderate & - & $\begin{array}{c}22 \\
(22.4 \%)\end{array}$ & $\begin{array}{c}22 \\
(15.0 \%)\end{array}$ \\
\hline Insignificant & - & $\begin{array}{c}6 \\
(6.1 \%)\end{array}$ & $\begin{array}{c}6 \\
(4.1 \%)\end{array}$ \\
\hline Total & $\begin{array}{c}49 \\
(100 \%)\end{array}$ & $\begin{array}{c}98 \\
(100 \%)\end{array}$ & $\begin{array}{c}147 \\
(100 \%)\end{array}$ \\
\hline
\end{tabular}

\subsection{Suggestions from the study for improvement}

To improve information provision on health and safety management at the mine, the following recommendations are provided:

(i) Provision of educational development opportunities for employees, especially the junior staff, should be encouraged at the mine. Management should sponsor the junior staff with general and basic education to pursue further studies in health and safety programmes, and to attend more seminars and conferences so that they would be more equipped with the required knowledge and skill. If this is done the 
employees will be able to assimilate information on health and safety risks.

(ii) It is again recommended that the frequency at which health and safety training programmes is organised should be increased.

\section{Conclusions}

A well managed information system is required in every establishment for various purposes including prevention or reduction in incidence of health and safety risks and diseases among employees. As it is susceptible to health and safety risks the TM of GGL has put in place effective information management system through which health and safety risk information is communicated to employees at the right time, at the right place, in the right form and to the right person. It is evidently clear that the effective provision of health and safety information to employees, through various media and methods, has resulted in the minimization and prevention of accidents and other forms of health and safety risks in the mine. The mine has created awareness among the employees of the existing health and safety policy of the mine. Meanwhile there is low literacy rate among the junior staff category employees of the TM of GGL which needs to be improved. As managers, researchers or employees the results of the study provide an insight into information management practices for the purpose of enhancing the health and safety of employees at work settings such as mining companies.

\section{Acknowledgements}

The authors are grateful to the employees of the Tarkwa mine of Goldfields Ghana Limited for volunteering to provide data for the work, and to Prof. Daniel Mireku-Gyimah for providing useful suggestions, invaluable encouragement and constructive criticism of the original manuscript.

\section{References}

Aina L. O. (2004), Library and information science text for Africa, Third World Information Services Limited, Ibadan, pp. 1-3.

Aina L. O. (2004), Library and information science text for Africa, Third World Information Services Limited, Ibadan, pp. 2-3.

Anon (2009a),"Screening criteria for medical injury",www.mcw.edu/medicalinjury, Accessed 9 March, 2010.

Anon (2009b), “Atumpan”, Goldfields News Magazine, vol. 23, pp. 4-5.

Buckland, M (1991), Information and information system, Praeger, New York, 225 pp.
Haag, S (2005), Management information systems for the information age, $5^{\text {th }}$ ed, McGraw-Hill, Boston, 554 pp.

Nyoni, S. L (1998), "Information Management and challenges for development",Records Management Bulletin, no. 85, p. 6.

Rabe-Sibli, B (2010), “A review of occupational health and safety practices at Goldfields Ghana Limited, Tarkwa Mine", Unpublished BSc Project Work, University of Mines and Technology, Tarkwa, p.19.

Reida, G. E. (2008), Principles of risk, management and insurance, $10^{\text {th }}$ ed., Pearson, Boston, 747 pp.

Robek, M. F. (1995), Information and records management: document-based information systems, $4^{\text {th }}$ ed., GLENCOE, New York, 600 pp.

Senn, A. J. (1982), Information systems in management, Wardsworth Publishing Company, Belmont, 525 pp.

Saunders, M., Lewis, P. and Thornhill, Adrian (2012), Research methods for business students, $6^{\text {th }}$ ed, Prentice Hall, New Jersey, pp. 265-266.

Strictland, A. J. and Thompson, A. A. (1998), Cases in strategic management, $10^{\text {th }}$ ed., McGraw-Hill, Boston, 691 pp.

Turner, P. (2010), "Mine worker dies at Tarkwa", Daily Graphic, Monday 26 ${ }^{\text {th }}$ July 2010, pp. 19.

White, M. (1981), Profit from information: a guide to the establishment, operation and use of information consultancy, Andre Deutsch Ltd, London, $118 \mathrm{pp}$.

Wlodowsky, R. J. (1985a), Enhancing adult motivation to learn, C. A. Jossey-Bass, San Francisco, 314 pp.

\section{Authors}

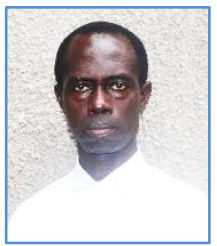

Yaw Ofori is an Assistant Librarian at the University of Mines and Technology, Tarkwa with a wide range of experience in the library profession. He obtained MA in Library Studies and BA in Information Studies in 2010 and 2004 respectively from the University of Ghana. His research interest includes providing information for employee safety in mining companies; and enabling effective use of library in secondary schools.

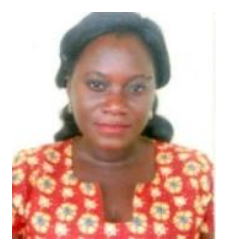

Gloria Pomfowaa is an Assistant Librarian at the University of Mines and Technology, Tarkwa with a wide range of experience in the library profession. She holds MA (Library Studies); BA (Social Sciences) from the University of Ghana. Research interest includes security of library books in academic libraries; managing library users' expectations; and reference service management. 